\title{
Making sense of global value chain-oriented policies: The trifecta of tasks, linkages, and firms
}

\author{
Carlo Pietrobelli ${ }^{1,2}$ \\ Roberta Rabellotti ${ }^{3}$ and \\ Ari Van Assche ${ }^{4}$ \\ ${ }^{1}$ Roma Tre University, Via Silvio d'Amico 77, \\ 00145 Roma, Italy; ${ }^{2}$ UNU-MERIT, Maastricht, \\ The Netherlands; ${ }^{3}$ Università di Pavia, Strada \\ Nuova 65, 27100 Pavia, Italy; ${ }^{4}$ HEC Montréal, \\ 3000 chemin de la Côte-Sainte-Catherine, \\ Montréal, Québec H3T2A7, Canada \\ Correspondence: \\ C Pietrobelli, Roma Tre University, Via Silvio \\ d'Amico 77, 00145 Roma, Italy \\ e-mail: carlo.pietrobelli@uniroma3.it
}

\begin{abstract}
In this article, we take stock of the nature and scope of global value chain (GVC)-oriented policies. Building on the papers that have been accepted to the special collection, we categorize GVC-oriented policies according to four different policy objectives: participation, value capture, inclusiveness, and resiliency. We compare and contrast the social and economic rationales for state intervention across the different types of GVC-oriented policies and discuss the instruments and actions at the disposal of governments to reach their policy objectives. The trifecta of tasks, linkages, and firms explains whether and how GVC-oriented policies differ from traditional public policies. Journal of International Business Policy (2021).
\end{abstract} https://doi.org/ | 0.1057/s422 14-021-001 17-6

Keywords: global value chains; policy; participation; value capture; inclusiveness; resiliency

\section{INTRODUCTION}

The emergence of global value chains (GVCs), characterized by companies' fine slicing of the production process across different countries and specializing in specific tasks, has typified the evolution of the global economy since the early 1990s (Zhan, 2021). GVC trade in intermediate goods and services produced by different actors in different places in the world grew rapidly until the outbreak of the global financial crisis in 2008, and since then it has stagnated, being affected by the recent increase in protectionism and by the abrupt halt caused by the COVID-19 crisis (Baldwin \& Evenett, 2020). Nevertheless, half of world trade is still related to GVCs (World Bank, 2019), and accordingly during the last two decades the GVC framework has turned into an influential development paradigm in policy circles. Evidence abounds that GVCs are a powerful driver for countries' economic growth (Stolzenburg et al., 2019; World Bank, 2019), increasing productivity (Constantinescu et al., 2019; Montalbano et al., 2018; Pahl \& Timmer, 2020), and generating employment (Van Assche, 2017). A wide range of governments and international organizations have thus included the GVC framework in regional, national, and global 
development strategies (Buckley, 2009; Gereffi, 2019b; Taglioni \& Winkler, 2016).

GVCs can boost economic performance through two key mechanisms: functional specialization and knowledge connectedness. First, GVCs give rise to a finer-grained international division of labor than was previously considered, which occurs at the task rather than the product level, allowing countries or regions to functionally specialize in those value chain stages in which they have a comparative advantage, letting domestic resources flow to their most productive use (Grossman \& Rossi-Hansberg, 2008). This functional specialization is considered crucial for developing countries that do not have the capabilities to produce complete products. They can embark on a fast track to industrialization by focusing on simpler production stages that suit their existing level of capabilities (World Bank, 2019). It also benefits developed countries which can specialize in high-value-added intangible-intensive tasks such as $\mathrm{R} \& \mathrm{D}$, management, and marketing while de-specializing in manufacturing (Buckley et al., 2020; Timmer, Miroudot \& de Vries, 2019; Van Assche, 2020).

A second mechanism through which GVCs generate economic growth is by spurring a region or country's global knowledge connectedness. The internationalization of value chains connects local firms with production partners across the globe, and this provides access to foreign knowledge that can strengthen the domestic technological capabilities required to economically upgrade (Ambos et al., 2021; Amendolagine et al, 2019). The GVC literature has primarily focused on the upgrading opportunities that global knowledge connectedness generates for suppliers in developing countries (Gereffi et al., 2005; Morrison et al., 2008). GVC linkages can help these suppliers to improve their technological capabilities by exposing them to new information and knowledge that can influence their dynamic learning paths (De Marchi et al., 2020) and boost aggregate economic development (Sako \& Zylberberg, 2019). International business studies, then again, have shown that the gains from global knowledge connectedness also apply to developed countries (Cano-Kollmann et al., 2016). Many lead firms deliberately establish linkages to other locations to tap into pockets of complementary knowledge and resources that are unavailable or more expensive locally (Bathelt et al., 2004), boosting local innovation performance (Turkina \& Van Assche, 2018).

There is a growing appreciation in the academic community that the GVC reality adds several layers of complexity to the link between international business and economic development, thus requiring new policy thinking. One group of scholars has advocated that GVCs call for a new type of industrial policy which focuses on the development and attraction of fine-grained GVC activities and an emphasis on the importance of leveraging international supply chain linkages (Gereffi \& Sturgeon, 2013; Milberg, Jiang \& Gereffi, 2014). Another group of researchers has called for governments to adopt a supply chain mindset in their thinking about trade and investment policies by focusing on how to allow domestic firms to establish rapid, efficient, and reliable linkages with their foreign value chain partners (Van Assche, 2017; Pietrobelli, 2021b). Yet a third group of studies has argued that GVCs push policy to move away from the market fundamentalism of the Washington Consensus (Werner, Bair \& Fernandez, 2014), contending that the advent of GVCs calls for a multi-scalar framework going beyond traditional approaches either focused on the nation state or the firm (Pietrobelli \& Staritz, 2018).

Despite this variety of arguments, there has been little systematic discussion about how GVC-oriented policies differ from traditional industrial, innovation, and international business policies. One reason is the relatively young age of the GVC research field. With scholars only starting to pay attention to the phenomenon 25 years ago, many aspects of the GVC framework have not been fully developed theoretically or tested empirically. This is exemplified by the lack of agreement on how to conceptualize and empirically measure economic upgrading (Gereffi, 2019a; Tokatli, 2012; Van Assche \& Van Biesebroeck, 2018), and points to new areas of research in which the GVC framework should expand. Another reason is the multi-disciplinary character of GVC research. GVCs have attracted the attention of scholars across fields including international business, international economics, economic geography, economic sociology, development studies and political science, but researchers have mostly analyzed the phenomenon within their own discipline's frame of reference, thus making it difficult to compare their findings.

This special collection of the Journal of International Business Policy (JIBP) is an opportunity to methodically reflect on the nature and scope of GVC-oriented policies and on how they compare with traditional public policies (see Table 1 for the list of papers). The collection of 11 articles addresses two broad sets of questions: How do GVC policies differ from the public policy efforts of 
Table 1 Special collection papers ordered by first appearance in the editorial

\begin{tabular}{|c|c|c|}
\hline Authors & Title & Publication issue \\
\hline $\begin{array}{l}\text { Pietrobelli, C., Rabellotti, R. \& } \\
\text { Van Assche, A. }\end{array}$ & $\begin{array}{l}\text { Making sense of global value chain-oriented policies: The trifecta } \\
\text { of tasks, linkages, and firms }\end{array}$ & Vol. 4, Issue 3 \\
\hline Jaax, A. \& Miroudot, S. & $\begin{array}{l}\text { Capturing value in GVCs through intangible assets: The role of } \\
\text { the trade-investment-intellectual property nexus }\end{array}$ & Vol 4, Issue 3 \\
\hline Findlay, C. \& Hoekman, B. & $\begin{array}{l}\text { Value chain approaches to reducing policy spillovers on } \\
\text { international business }\end{array}$ & Vol 4, Issue 3 \\
\hline $\begin{array}{l}\text { Bam, W., De Bruyne, K., \& } \\
\text { Laing, M. }\end{array}$ & $\begin{array}{l}\text { The IO-PS in the context of GVC-related policymaking: The case } \\
\text { of the South African automotive industry }\end{array}$ & Vol 4, Issue 3 \\
\hline Gereffi, G., Lim, H.-C. \& Lee, J. & $\begin{array}{l}\text { Trade policies, firm strategies, and adaptive reconfiguration of } \\
\text { global value chains }\end{array}$ & Vol 4, Issue 4 \\
\hline De Marchi, V. \& Alford, M. & $\begin{array}{l}\text { State policies and upgrading in global value chains: a systematic } \\
\text { literature review }\end{array}$ & Vol 5, Issue 1 \\
\hline $\begin{array}{l}\text { Pegoraro, D., De Propris, L., \& } \\
\text { Chidlow, A. }\end{array}$ & $\begin{array}{l}\text { Regional factors enabling manufacturing reshoring strategies: A } \\
\text { case study perspective }\end{array}$ & Vol. 5, Issue 1 \\
\hline $\begin{array}{l}\text { Goerzen, A., Iskander, S., \& } \\
\text { Hofstetter, J. }\end{array}$ & $\begin{array}{l}\text { The effect of institutional pressures on business-led interventions } \\
\text { to improve social compliance among emerging market } \\
\text { suppliers in global value chains }\end{array}$ & Vol 4, Issue 3 \\
\hline $\begin{array}{l}\text { Pasquali, G., Godfrey, S. \& } \\
\text { Nadvi, K. }\end{array}$ & $\begin{array}{l}\text { Understanding regional value chains through the interaction of } \\
\text { public and private governance: Insights from Southern Africa's } \\
\text { apparel sector }\end{array}$ & Vol. 4, Issue 3 \\
\hline Nachum, L. & $\begin{array}{l}\text { Value distribution and markets for social justice in global value } \\
\text { chains: Interdependence relationships and government policy }\end{array}$ & Vol. 4, Issue 4 \\
\hline $\begin{array}{l}\text { Gammelgaard, J., Haakonsson, } \\
\text { S. \& Just, S. }\end{array}$ & $\begin{array}{l}\text { Linking Malawi's agricultural sector to global value chains: The } \\
\text { case for community governance }\end{array}$ & Vol. 4, Issue 4 \\
\hline Horner, R. & $\begin{array}{l}\text { Global value chains, import orientation, and the state: South } \\
\text { Africa's pharmaceutical industry }\end{array}$ & Vol 5, Issue 1 \\
\hline
\end{tabular}

the past? What are the desirable future evolution paths of GVC-oriented policies? That is to say, the special collection addresses both positive and normative aspects of GVC-oriented policies, offering suggestions for future research.

In this editorial introduction, we build on the findings of the collected articles to develop a framework which allows for a methodical analysis of existing studies on GVC-oriented policies. The framework categorizes GVC-oriented policies according to four different policy objectives - participation, value capture, inclusiveness, and resilience - and investigates how each type of policy is built on different economic rationales and proposes distinct policy instruments. Finally, we use the trifecta of tasks, linkages, and firms to explain whether and how GVC-oriented policies differ from traditional public policies.

\section{OBJECTIVES, RATIONALES, AND INSTRUMENTS OF GVC-ORIENTED POLICIES}

We define GVC-oriented policies as the spectrum of socio-economic tools and actions that governments use to influence GVCs and their actors so that they can secure local, regional, and national interests in a wide array of areas.

Table 2 presents the main identifying dimensions characterizing these policies: (a) their economic and social objectives; (b) the economic rationales explaining why policy intervention is necessary to attain these goals; and (c) the wide range of instruments and actions needed to achieve them. The table offers a summary of the analytical framework, which is elaborated in detail in what follows.

The first identifying dimension is the policy objective. According to Pietrobelli and Staritz (2018), GVC-oriented policies are aimed at accomplishing a mixture of objectives that are not necessarily complementary or compatible. They stress three main distinct policy goals: (1) strengthening the local economy's participation in GVCs; (2) enhancing the local economy's value capture in GVCs; and (3) improving local social and environmental conditions in GVCs. The Covid-19 pandemic has put a fourth objective front-and-center in policy debates around GVCs: strengthening a country's economic resiliency against global 
Table 2 GVC-oriented policies: objectives, rationales, and instruments

\begin{tabular}{|c|c|c|c|}
\hline Policy type & Objectives & Dominant economic rationale & Policy instruments \\
\hline $\begin{array}{l}\text { GVC participation } \\
\text { policies }\end{array}$ & $\begin{array}{l}\text { Enter in and } \\
\text { enhance the } \\
\text { local } \\
\text { participation in } \\
\text { GVCs }\end{array}$ & $\begin{array}{l}\text { Reduce market distortions with horizontal } \\
\text { policies: } \\
\text { - Market-enabling policies to assist the private } \\
\text { sector in restructuring productive activities } \\
\text { according to latent comparative } \\
\text { advantages } \\
\text { - Connectedness policies to reduce the costs } \\
\text { related to linking domestic GVC activities } \\
\text { to foreign value chain partners }\end{array}$ & $\begin{array}{l}\text { - Policies for creating an enabling business } \\
\text { environment; } \\
\text { - Elimination of trade obstacles; } \\
\text { - Strengthening of competition; } \\
\text { - Improvement of transport and digital } \\
\text { infrastructures; } \\
\text { - Education and training policies }\end{array}$ \\
\hline $\begin{array}{l}\text { GVC value capture } \\
\text { policies }\end{array}$ & $\begin{array}{l}\text { Strengthen value } \\
\text { creation and } \\
\text { capture in GVCs }\end{array}$ & $\begin{array}{l}\text { Vertical policies to foster growth through } \\
\text { economic upgrading justified by } \\
\text { - power asymmetries between lead firms and } \\
\text { their suppliers; } \\
\text { - upgrading involving costs, risks, and } \\
\text { uncertainty with the potential of } \\
\text { generating spillovers to the domestic } \\
\text { economy; } \\
\text { - need for coordination of different actors } \\
\text { investing along the chain }\end{array}$ & $\begin{array}{l}\text { - Strengthening of local innovation and } \\
\text { production ecosystems; } \\
\text { - Building and improving specific types } \\
\text { (logistical, digital, and productive) of } \\
\text { infrastructures: } \\
\text { - Development of specific skills; } \\
\text { - Establishment of linkages between } \\
\text { universities, vocational centers and firms } \\
\text { involved in GVCs; } \\
\text { - Provision of advisory services in the areas } \\
\text { of standards, metrology, testing, and } \\
\text { certifications; }\end{array}$ \\
\hline $\begin{array}{l}\text { GVC inclusiveness } \\
\text { policies }\end{array}$ & $\begin{array}{l}\text { Improve social } \\
\text { and } \\
\text { environmental } \\
\text { conditions in } \\
\text { GVCs }\end{array}$ & $\begin{array}{l}\text { - Economic upgrading does not } \\
\text { automatically foster social and } \\
\text { environmental upgrading. } \\
\text { - Lead firms can be a powerful vector to } \\
\text { promote social and environmental } \\
\text { upgrading but } \\
\text { - they need motivation; } \\
\text { - they need support from national and } \\
\text { supranational policies }\end{array}$ & $\begin{array}{l}\text { - Improvement of labor, social, and } \\
\text { environmental regulations and their } \\
\text { enforcement; at national and } \\
\text { supranational levels. } \\
\text { - Responsible sourcing policies; } \\
\text { - Private standard promotion; } \\
\text { - Involvement of local communities in GVC } \\
\text { governance }\end{array}$ \\
\hline $\begin{array}{l}\text { GVC resiliency } \\
\text { policies }\end{array}$ & $\begin{array}{l}\text { Strengthen the } \\
\text { local economic } \\
\text { resilience }\end{array}$ & $\begin{array}{l}\text { - Participation in GVCs influences resilience } \\
\text { by affecting both the severity of a } \\
\text { disruption's initial economic impact and } \\
\text { the ability to rapidly bounce back post- } \\
\text { disruption; } \\
\text { - Resilience policy should ensure that } \\
\text { countries' ability to deliver essential goods } \\
\text { and services is sufficiently resistant to both } \\
\text { local and foreign disruptions }\end{array}$ & $\begin{array}{l}\text { - Supply chain resilience stress test; } \\
\text { - Diversification policy; } \\
\text { - Public procurement policy; } \\
\text { - Reshoring policy; } \\
\text { - International cooperation to share } \\
\text { essential goods, to conduct joint } \\
\text { procurements at a bilateral or regional } \\
\text { level and to limit export restrictions }\end{array}$ \\
\hline
\end{tabular}

economic shocks (Miroudot, 2020). In this paper, we propose four types of GVC policies:

- GVC participation policies aimed at entering in and enhancing the local economy's participation in GVCs;

- GVC value capture policies intended for strengthening the local economy's value creation and capture within GVCs;

- GVC inclusiveness policies directed to improve the local social and environmental conditions in GVCs;
- GVC resiliency policies designed for strengthening the local economy's resiliency.

The second characterizing dimension is the rationale adopted by governments for justifying their policy interventions. A first reason for public interventions is to eliminate market distortions that inhibit local GVC activities from reaching the envisioned goals. Market distortions can provoke a suboptimal allocation of resources by sending the private sector wrong signals. For example, restrictions in factor markets and constricting regulations 
can prevent the competitive pricing of production factors. Trade policies such as tariffs and subsidies may inhibit the reallocation of resources toward sectors and value chain activities with comparative advantages. Policy tools that eliminate such market distortions are thus considered instrumental if they can help a country improve its GVC participation, strengthen its value capture, entice social and environmental upgrading, and buttress economic resiliency. For example, improving customs and border procedures and enhancing port and transportation infrastructures are considered critical for integrating a country into GVCs since these measures reduce barriers of trade both on the import and export side.

A second justification for public interventions is to address externalities in GVCs that interfere with the attainment of policy goals. A first type of externality is related to risks, uncertainty, and incomplete information, which limits companies' private investments to join GVCs, to engage in transactions with suppliers and to invest in innovation and learning activities aimed at upgrading. Examples of related externalities abound in GVCs such as lead firms searching for foreign buyers through customs documents and employee informal exchanges - which may unwittingly generate information that could benefit other lead firms, therefore incentivizing free-riding behavior and decreasing the incentive to invest in searches for new buyers (Blyde, Pietrobelli \& Volpe, 2014). Similarly, firms could be investing in improving technical and management practices to fulfil quality standards and achieve certifications. By doing so, firms send a signal and provide information that could motivate and help other firms fulfil the same standards, causing at the same time a positive (the signal) and a negative (the free-rider use of information) externality. Besides, externalities generated by the GVC lead firms through knowledge flows and technical assistance offered to suppliers may lead them to underestimate the advantages of investments in GVCs linkages (and raise the incentive to free-riding behavior), and therefore to suboptimal investments in suppliers' development.

The uneven distribution of power and economic gains between lead firms and their suppliers can also generate GVC-related externalities. Lead firms have the power to define the terms and conditions of value chain participation, thus affecting whether and how local suppliers and workers get involved (Buckley \& Strange, 2015; Gereffi et al., 2005), and influencing their dynamic learning paths that may facilitate or hamper economic and social upgrading (Barrientos et al., 2011; Pietrobelli \& Rabellotti, 2011). Such power asymmetries can be both the cause and consequence of market failures. A lead firm's power may in some cases derive from a monopoly position created with the help of government protections of intellectual property (Durand \& Milberg, 2019). In other cases, corporate power may create market failures by hindering the ability of domestic firms to capture economic and social gains from GVC participation (Pietrobelli \& Staritz, 2018).

GVCs may also lead to a discrepancy between the vulnerabilities that market players and governments are willing to be exposed to. Shortages in the supplies of essential intermediate goods, or the sudden closure of demand outlets, are notable risks that require mitigation and adaptation strategies at the firm-level, but also policies at the country-level, as illustrated by the cases of face masks and respirators in the United States during the COVID-19 pandemic (Gereffi, 2020).

GVC-related externalities may also take the form of coordination failures. For example, coordination among firms may be needed for industries related through backward and forward linkages. An assembly plant might not start operations in a given location because it lacks local suppliers of a particular component, but a potential supplier of that component might not initiate production because there is no local downstream demand for its product (Trindade, 2005).

The final differentiating dimension is represented by the instruments and actions at the disposal of the policy makers to reach GVC-oriented policy objectives. Horner (2017) suggests four types of actions to either buttress or harness GVCs: (a) the government can act as a facilitator by eliminating market distortions through policies in areas such as trade, investment, and innovation; (b) it can be a regulator by restricting the negative externalities of private market transactions and by mitigating the unequal distributive impact of markets through, among others, rules about standards and labor conditions; (c) it can be a producer by directly engaging in state-owned production activities and finally d) it can be a buyer procuring products and services via state-led value chains, which may comprise distinct economic, social, and environmental requirements.

There is a general acknowledgement that countries and regions tailor their GVC-related objectives, rationales, and instruments to their socio- 
economic context, but guidance has remained exceedingly general. What specific instruments could help workers, firms, regions, and countries to benefit from GVCs, and how they work, has been left implicit and hardly tackled systematically in the literature. For example, policies that are meant to attract GVCs (e.g., integrate firms into a value chain) are very different from policies aimed at capturing the possible but uncertain economic and social gains from GVC integration (Barrientos et al., 2011; Pietrobelli \& Staritz, 2018; Lema, Pietrobelli $\&$ Rabellotti, 2019). Moreover, these policy prescriptions have often ignored economic resilience which has emerged as a priority related to GVCs in the wake of recent system-wide crises. In the next section, we analyze in detail the four main categories of GVC-oriented policies identified above, offering examples of the different measures adopted across a variety of developed and developing contexts.

\section{TYPES OF GVC-ORIENTED POLICIES}

The articles in this special collection present new, original evidence, which combined with the existing literature, offers the opportunity for a closer scrutiny of the proposed four types of GVC policies: participation policies; value capture policies; inclusiveness policies; and resiliency policies.

\section{GVC Participation Policies}

GVC participation policies have gained great traction in policy circles in the past two decades for two main reasons. First, as already discussed, there is substantial empirical evidence that GVC participation is a powerful driver for a location's economic performance (Stolzenburg, et al., 2019; World Bank, 2019). Second, as explored below, policies to spur GVC participation encompass many of the liberal market-enabling and connectedness policies that policymakers have traditionally embraced.

Given the central roles of functional specialization and global connectedness in the GVC-growth nexus, the focus is concentrated on two policy pillars that attempt to reduce market distortions: market-enabling policies that assist the private sector in restructuring productive activities according to a country's latent comparative advantage and connectedness policies that reduce the costs related to linking domestic firms to foreign value chain partners. Both policies are horizontal in nature because they do not imply targeting specific sectors
(Crespi, Fernandez-Arias \& Stein, 2014, Pietrobelli, 2021b).

Market-enabling policies are aimed at addressing the market distortions that prevent the allocation of private resources toward comparative advantage sectors and value chain activities. Eliminating such market distortions is thus considered instrumental to facilitating GVC participation and promoting a country's functional specialization in those GVC activities in which a country has a latent comparative advantage. They include the deregulation of factor markets and the strengthening of competition as well as the removal of barriers to business creation and operation and policies for creating an enabling business environment for foreign direct investments.

Connectedness policies aim at improving GVC participation by reducing the cost for local firms to receive or transmit goods and information across borders, thus turning them into more attractive GVC partners. On the goods side, there are policies that reduce trade costs such as the elimination of tariff and non-tariff barriers and costs related to delays and uncertainty through customs reforms as well as policies aimed at the introduction of competition in transport services and at the improvement of port structure and governance. On the information side, there are policies that strengthen companies' ability to transfer data cheaply, freely, and safely across borders, such as those aimed at fostering competition in the telecommunications sector and at improving the quality of the wireless network infrastructure.

In this special collection, Jaax and Miroudot (2021) provide new empirical evidence about a cocktail of market-enabling and connectedness policies, which can help countries to increase their returns to intangible assets in GVCs. This is a welcome addition to the literature since the share of intangibles in GVC income has increased and the related rents have steepened in the past two decades (Chen et al., 2018; Van Assche, 2020). The authors combine the OECD's Trade in Value Added dataset with data on factor income to show that trade and investment openness, intellectual property protection, and competition enforcement are all positively associated with returns to intangible assets in GVCs.

More work is nonetheless needed to identify and eliminate the main trade costs and other market distortions that prevent firms from participating in GVCs. Findlay and Hoekman (2021)'s article in this special collection is in that respect a useful 
contribution. They identify the rising salience of differences in regulatory regimes and policies as a main factor impacting trade and operating costs. According to them, there is a need for multistakeholder initiatives to improve the cost efficiency of regulatory enforcement processes. There is benefit in businesses cooperating with other stakeholders to identify and tackle policy impediments to the efficient operation of GVCs.

A careful observer will note that the marketenabling and connectedness policies to boost GVC participation bear important similarities with traditional development strategies built around the so-called Washington Consensus (Gereffi, 2019b). Indeed, neoliberal convictions about comparative advantage, competitiveness, transaction costs, and minimalist state intervention are all easily accommodated within GVC participation policies, easing their adoption by national governments and international organizations.

Nonetheless, several features differentiate GVC participation policies from traditional trade policies. First, specialization is considered to take place at the disaggregated task level instead of the industry level. Second, connectedness policies are put on a higher pedestal. There are several reasons why reducing trade costs is considered disproportionately important in a GVC setting. In GVCs, the same component often crosses borders multiple times, therefore compounding the effect that trade costs have on the final price. Adding to this, production delays associated with trade impediments can have cascading effects throughout the chain. Keeping trade costs at bay is thus considered critical for GVC participation. Third, connectedness policies provide more room for unilateral state action than traditionally thought. Whereas eliminating trade costs on the export side generally requires governments to negotiate a reciprocity of concessions with other countries, reducing tariffs and non-tariff barriers on the import side can be done one-sidedly. Behind the border measures that improve port and telecommunications infrastructure can also be unilaterally addressed.

\section{GVC Value Capture Policies}

An influential stream of research has been vocal in advocating that the GVC framework lends itself to policy recommendations that go far beyond the relatively minimalist, facilitative, and horizontal GVC participation policies (Gereffi, 2019b). While this research recognizes the possibility for firms and locations to effectively learn and develop from
GVC participation, it cautions that the presence of multiple market and coordination failures implies that market forces do little to guarantee that GVC participation goes together with increased value capture (Pietrobelli \& Staritz, 2018). For these scholars, governments thus need to adopt far more interventionist GVC value capture policies to ensure a strong nexus between GVC participation and industrialization through structural transformation (Mayer \& Phillips, 2017). Since these policies tend to target specific sectors, tasks, or firms, they are often more vertical in nature compared to GVC participation policies.

The starting point of the argument is that GVC participation generates the biggest bang for its buck if it can improve the development of production and innovation capabilities so that firms and countries can boost the value added that they can create and appropriate within a GVC through local learning and innovation (Pietrobelli \& Rabellotti, 2011). In the GVC literature, this process has been termed economic upgrading, and it refers to strategies that countries and firms might implement to move towards higher value-added activities (Gereffi et al., 2005). Different forms of economic upgrading have been identified: product and process upgrading, which implies moving vertically along the value chain to better products or processes as well as the more challenging functional and interchain upgrading, entailing horizontal movement towards new functions or new markets (Humphrey \& Schmitz, 2002). The concept of economic upgrading has been widely used but many empirical and conceptual challenges have also been raised in the literature. Gereffi (2019a) stresses how the large amount of empirical evidence collected in a wide variety of industries and countries shows that the upgrading process is not at all linear and inevitable as it is sometimes assumed.

More generally, this discussion on the potential benefits from GVC integration, and the related economic upgrading, is crucially related to the capacity to generate, appropriate, and protect static and dynamic rents. Rents describe an environment of scarcity facing an existing demand, where the holder of rents benefits from an absence of competition, protected by one or more entry barriers (Davis et al., 2018). Where such barriers cannot be protected, it is the ability to generate "dynamic rents", which provides for sustainable incomes.

The policy challenge is that market and coordination failures render the link between GVC participation and economic upgrading a highly 
uneven process with up and downgrading sometimes coexisting (Ponte \& Ewert, 2009) and with economic upgrading outcomes varying across firms within countries, often leaving smaller and rural firms behind (Martinez-Covarrubias et al., 2017).

First, it has been stressed that the quality of international knowledge flows critically depends on the governance patterns that lead firms adopt with their suppliers as well as their bargaining power (Schmitz \& Knorringa, 2000). For example, lead firms are generally willing to tolerate or even support upgrading by their suppliers along the dimensions of quality, flexibility, and productivity if it helps strengthen the complementarities between value chain partners. In contrast, lead firms may discourage and even hinder the acquisition of technological capabilities by their suppliers if in the future this type of upgrading risks to encroach on the lead firm's core competence (Navas-Aleman, 2011).

Second, the quality of international knowledge flows also depends on local firms' ability to absorb, master, and adapt the knowledge and capabilities that lead firms transfer to them (Morrison et al., 2008). These firm-level processes often suffer from important failures in developing countries, where firms have low R\&D and innovation capabilities. In these circumstances, an easy shortcut is to buy or borrow foreign technologies requiring little absorption capacities, or to specialize in less technically sophisticated methods or assembly manufacturing. In such instances, effective forms of government policy should include various ways to cultivate R\&D and innovation capability itself (Lee, 2013). Furthermore, Lema et al. (2019) have underlined the role played by the multiple interactions between GVCs and innovation systems in shaping the speed, depth, and overall opportunity for upgrading at country and firm levels.

There is thus a clear role for GVC policies aimed at enhancing the capture of value produced in GVCs as, first, power asymmetries between lead firms and their suppliers might hinder the ability to seize economic gains from GVC participation; second, upgrading in GVCs involves costs, risks, and uncertainty with the potential of generating spillovers to the domestic economy, and third, there is a need for coordination of different actors investing along the chain (Pietrobelli \& Staritz, 2018).

At the macro level, there is an issue related to identifying which parts of the GVC should be targeted with interventions to foster both short- and long-term growth through economic upgrading. Gereffi and Sturgeon (2013) argue that industrial policy in the age of GVCs must go beyond recreating entire supply chains within a national territory and needs to explicitly utilize extraterritorial linkages that affect a country's positioning in GVCs. However, this says little about the type of tasks that need special promotion.

Bam, De Bruyne, and Laing (2021) in this special collection suggest employing an input-output product space (IO-PS) framework to evaluate the effectiveness of industrial policies on specific GVC tasks over time. They argue that industrial policies can boost capacity development by (i) vertically supporting economic upgrading within GVCs and (ii) horizontally unlocking opportunities in tasks that are close in technological space but not necessarily part of the same GVC. Both need to be considered when predicting the impact of industrial policy on GVC tasks. They apply it to the automotive chain in South Africa showing that subindustries, such as bearings, passenger vehicle bodies, and passenger vehicles, are good targets that will contribute to short-term growth while vehicle parts and motorcycles and cycles could help to develop capabilities that might support the expansion of other high potential products in the future. In general, the IO-PS approach is useful because it allows for an immediate identification of those product categories within the value chain offering more opportunities for future value capturing in the short and long term, orienting policies to focus on the underdeveloped parts of particular industries.

Maintaining a focus on macro policies, trade restrictions can also have unintended consequences on economic upgrading, as explained in this special collection by Gereffi, Lim, and Lee (2021), who explore the impact of the US-China trade war on GVCs. The authors argue that in the case of the electronics GVC, besides the expected switching of production locations, end markets, and suppliers, a side effect is the introduction of strategies to develop new capabilities among domestic suppliers and to functionally upgrade by incorporating new activities. A case in point is Huawei, which has started to develop its own operating system and to internalize chip production to reduce its reliance on US technology.

Another array of policies that can impact economic upgrading is the introduction of local content requirements and of restrictions on foreign investments. Local content policies are typically 
explained with the logic of infant industries, granting the temporary breathing space to local firms to enable them to learn and catch up the initial disadvantage. De Marchi and Alford (2021) in this special collection present the Chinese experience in the electric vehicle industry as an illustrative case in which restrictions have been adopted to force global lead firms to collaborate with local producers, facilitating transfer of stateof-the-art technologies. In China, similar policy measures have also been adopted in other industries, such as for instance those related to renewable energies, allowing a rapid upgrading in GVCs. Lema et al. (2020) show that the state has also played a key role in creating a domestic market which has been key for supporting the technological upgrading of domestic industries. The implementation of the Renewable Energy Law in 2006 and sectorfocused 'missions' such as the Rooftop Subsidy and the Golden Sun Demonstration Programs implemented in the solar sector, together with investments aimed at building domestic production and innovative capabilities, have supported the development of the domestic industries and the progressive upgrading of domestic companies within GVCs. In a different paper on the extractive industries, Anzolin and Pietrobelli (2021) stress that local content policies need to go hand in hand with policies to promote domestic capability building. Without the latter, the former loses their economic reason.

A related point is whether and how upgrading in some domestic firms could trickle down to the rest of the economy. Hansen and Hansen (2020) study the case of the Chinese biomass industry showing how the upgrading of a single producer in a GVC has created opportunities for several other domestic companies thanks to knowledge spillovers happening through labor mobility, supplier relations, demonstration effects and university-industry collaborations.

At the meso and micro levels, value-capture policies are aimed at strengthening and deepening innovation and production ecosystems by facilitating the process of building the firm-level production and innovation capabilities that are necessary for capturing such gains (Sako \& Zylberberg, 2019). Giuliani et al. (2005) show how the processes of upgrading at the firm level may be enhanced by the collective efficiency prevailing in local SME clusters. Based on detailed Latin American case studies, they also suggest that relational forms of GVC governance favor value capturing through firm- level upgrading, and that GVC integration often helps product and process upgrading, but rarely functional upgrading. These upgrading processes in turn also depend on the prevailing innovation systems, which interact and sometimes co-evolve with GVC governance in ways that may promote or hinder the development of innovation capabilities in firms (Lema, et al, 2019; Pietrobelli \& Rabellotti, 2011).

The importance of a well-developed, local business ecosystem is also stressed by Pegoraro, De Propris \& Chidlow (2021) in this special collection, who underline the role played by the ecosystem in assisting a company located in the West Midlands in the UK, in reshoring back its activities and building up a network of local suppliers, which resulted in an upgraded position of the region in GVCs.

In their extensive review of the existing GVC literature in this special collection, De Marchi and Alford (2021) present a detailed account, enriched by many examples across industries and countries, of policies aimed at value capturing. Among them, there are those aimed at building and improving different types (logistical, digital, and productive) of infrastructure, which can help to attract GVCs and also to facilitate upgrading within them. Besides improving countries' knowledge infrastructure, enhancing local capabilities to meet the changing and growing demand of local manufacturers is another important area for value capturing policies. This implies the development of education and training projects creating the specific skills local firms need for their integration into and upgrading within GVCs, and establishing links between universities, vocational centers and the firms involved in the chains. Pegoraro et al. (2021) emphasize the extremely proactive role played by the local chamber of commerce in the West Midlands in upgrading the skills of the local workforce to meet the needs of local manufacturers, in assisting firms to recruit the right staff, and in offering networking opportunities to share best practices among local enterprises.

The provision of advisory services in the areas of standards, metrology, testing, and certification is also particularly helpful in targeting value capture, because they can support local suppliers in developing the necessary capabilities for upgrading. One important service is the organization of online platforms to collect information about trusted and accredited suppliers, capable of delivering products and services matching the lead firms' requirements. 
The company studied by Pegoraro et al. (2021) reorganized its GVC by taking advantage of the information on domestic suppliers available in a platform established by the domestic industrial engineering association.

From this literature review, the first clear insight we may derive is that value capture policies imply a much more interventionist stance, with vertical interventions on specific sectors and even firms. The balance moves from the establishment of market-friendly conditions - by remedying market distortions to restore conditions favorable to the attraction of and integration into GVCs - to much greater selectivity and the addressing of externalities. In addition, the focus of industrial policy is currently much more on the role of tasks and nodes than on entire productive sectors. This requires a different approach relative to the industrial policies of the 1980s and 1990s - that mainly focused on raising barriers (Morris \& Staritz, 2019) - towards a multi-scalar perspective, accounting for sector specificities, inter-firm relations, and localized value-creation.

\section{GVC Inclusiveness Policies}

Sustainability challenges have emerged as a third policy priority related to GVCs. Sustainable development aims at a world that is prosperous, socially inclusive, and environmentally sustainable, yet today's economic and governance systems are poorly equipped to target this triple bottom line without the help of the private sector. Market forces, for one, have done little to narrow income inequalities within and across countries, to overcome deeply entrenched social discrimination by race and gender, or to protect the natural environment (Sachs \& Sachs, 2021). The global nature of many sustainability challenges has furthermore eroded the ability of countries to address these market failures (Scherer \& Palazzo, 2011). For these reasons, there has been growing research investigating how GVCs can be better harnessed through policy to enhance social and environmental upgrading.

GVC participation and economic upgrading do not automatically foster social and environmental upgrading. Even if they create significant economic progress, the benefits often leave many behind (Locke, 2013; Lund-Thomsen \& Lindgreen, 2014; Mayer \& Gereffi, 2010; Posthuma \& Nathan, 2010). Barrientos et al. (2011) show that economic upgrading can, but does not necessarily, lead to social upgrading which implies accessing better work and enhancing working conditions, protection and rights. Similarly, there could be tensions between economic and environmental upgrading, defined as any change in the value chain resulting in the reduction of firms' ecological footprint, such as in their impact on greenhouse gas emissions, on biodiversity losses and on natural resources overexploitation (De Marchi et al, 2019). Economic, social and environmental upgrading are clearly interlinked but the evidence available on how they interrelate is still rather limited. De Marchi et al. (2019) report about cases in which the three types of upgrading are part of a virtuous cycle like in the coffee value chain studied by Giuliani et al. (2017) in several Latin American countries, but also about value chains in which economic upgrading coincided with environmental downgrading like among Kenyan farmers investigated by Krishnan, te Velde and Were (2018).

At the same time, there is a growing acknowledgement that lead firms - if properly harnessed can be a powerful vector to promote social and environmental upgrading. Lead firms have the corporate power to define the terms and conditions of GVC membership and can use their authority to promote social standards and environmental stewardship among their suppliers. This compliance can cascade down to lower-tier suppliers if GVC participation is made conditional on promoting sustainability standards further down the chain (Narula, 2019). Distelhorst and Locke (2018) find that firms reward suppliers for complying with social standards, supporting the notion that lead firms can play a key role in promoting social upgrading.

The ability of lead firms to dictate the terms under which lower-level actors operate in a GVC has led to a vibrant academic debate about the role of private governance in filling gaps in global regulation. Many MNEs have implemented corporate social responsibility (CSR) initiatives in their supply chains as a way of independently regulating labor issues, including the establishment of codes of conduct and the implementation of third-party monitoring of working and environmental conditions. While several scholars have pointed out the positive role that private governance can play in addressing market failures that public governance has difficulties tackling (Scherer \& Palazzo, 2011), others have warned that it is relatively ineffective (Locke et al., 2019) and may weaken state regulation and create parallel regulatory systems (Rossi, 2019; Seidman, 2009). 
In this special collection, Goerzen, Iskander and Hofstetter (2021) add to this debate by studying the institutional conditions under which private governance can boost social upgrading. Specifically, they empirically evaluate if private and public governance are complementary by analyzing whether social standard compliance (measured through third-party audits) is higher in countries with competent and stable governments that are able to create and enforce labor and environmental legislations. Based on two longitudinal datasets that merge information at the firm level with World Bank's Worldwide Governance Indicators (WGI), the authors find that social standard compliance is enhanced by institutions that improve voice and accountability, but is weakened by institutions that improve the enforcement of rules and regulations. They conclude that it is important for policymakers to collaborate with GVC lead firms by recognizing certifications accredited by private bodies as equivalent to those provided by public standard agencies.

How to push lead firms to promote sustainability throughout their GVCs nonetheless remains an area of scholarly contention. A first concern is that many MNEs are unmotivated to address sustainability challenges. They either threaten their suppliers with too small a stick or cajole with too small a carrot to incentivize the adoption of social standards and environmental stewardship. Indeed, several scholars have blamed lead firms of heaping the costs of compliance upon the suppliers without installing effective cost-sharing, monitoring or penalty systems (Bird \& Soundararajan, 2020; Contractor \& Kundu, 1998; Locke et al., 2009). Bird et al. (2019) expand upon this, supporting the notion that suppliers face a trade-off between compliance with formal codes and employment standards on one hand, and productivity incentives on the other. Lead firms are alleged to go ahead with such ineffective governance schemes since they care more about "looking good" rather than "doing good" (Lund-Thomsen, 2020), undermining the ability of GVC participation to render social upgrading. Ponte (2020), for example, draws from empirical evidence on the coffee and wine value chains and shows that the mainstreaming of sustainability has allowed the global lead firms to accumulate 'green' profits by extracting value from suppliers in the Global South. This has been possible because suppliers have been made responsible for the risks and paying for the costs of sustainability compliance.
A second concern is that the lead firms do not have the capabilities to push suppliers to adopt higher social and environmental standards (Goerzen \& Van Assche, 2020). The diverse socioeconomic and cultural contexts of employment in which suppliers are embedded make it difficult for the lead MNEs to understand the bottlenecks that prevent compliance with social standards imposed from overseas (Lund-Thomsen \& Lindgreen, 2014).

Several papers included in this special collection show that national and supranational policies play a key role in fostering social and environmental upgrading. Pasquali, Godfrey \& Nadvi (2021) offer empirical evidence from Southern Africa's regional value chain in apparel that illustrates how difficult it could be improving labor standards when the national and regional contexts are characterized by weak labor legislation and fragile trade unions. In sharp contrast to AGOA and EBA, which respectively regulate trade between the USA and EU and African countries, and incorporate labor standards into trade preferences, neither SACU nor SADC, which regulate trade among African countries, integrate minimum labor standards. Their conclusion is that the future implementation of the African Continental Free Trade Area (AfCFTA) should include a social clause, because without it, for instance, South African retailers could take advantage of the very low labor costs in Ethiopia without any attention to social upgrading (Whitfield et al., 2020).

Along the same lines, Nachum (2021) in this special collection states that to push social upgrading there is a need for interdependence of objectives between producing and consuming countries. The author presents a comparative case about the apparel industry in Bangladesh and Cambodia. While in Cambodia the empowerment of labor unions supported by the local government and pushed by the US policy brought about social change, in Bangladesh, without national support, US lead firms were unable to instill any social improvement (Bair et al., 2020). This case illustrates that accounting for the interdependencies between lead firms, domestic suppliers, employees and national governments in producing and consuming countries is fundamental to instilling socially desirable value distribution in GVCs.

A further dimension which has not been considered as much in the literature is the potentially negative impact of large-scale production for global markets on local communities. This is the focus of Gammelgaard, Haakonsson and Just (2021) in this 
special collection who, based on empirical evidence on Malawi, introduce the concept of community governance as a bottom-up governance process to be undertaken by rural communities involved in agricultural GVCs. This entails designing and managing GVC participation with the aim of livelihood upgrading against potentially harmful GVC-related activities. Consequently, the state should play a role of regulator of corporate actors and mitigator of potential negative GVC effects, guaranteeing local communities' active participation in GVC governance.

Taken together, GVC studies have firmly established that lead firms can be a powerful vector to promote social and environmental upgrading through their linkages with their suppliers and sub-suppliers. However, the literature is much less clear which policies targeting lead firms and their linkages can most effectively promote sustainability along GVCs.

\section{GVC Resiliency Policies}

Economic resilience has emerged as a fourth priority related to GVCs in the wake of recent systemwide crises. In today's globally interconnected economies, a disruption in one part of the economic system can turn into a severe global economic downturn, and GVCs often play an important role in the transmission (Miroudot, 2020). Recent history provides us with several examples. During the global financial crisis of 2008-2009, negative liquidity shocks in one country caused a chain reaction of financial difficulties throughout GVCs as firms relied on each other for credit (Bems et al., 2013). In the immediate aftermath of the 2011 Tohoku earthquake and tsunami, the production of many Japanese automotive and electronics components dried up, creating a disruption of international supply chains that affected the price and availability of cars and computers around the world (Escaith et al., 2011). In the early months of the Covid-19 pandemic, confinement efforts in China led to the closure of factories across the globe as companies could not access parts (Foldy, 2020).

In policy circles, these events - combined with recent shortages in essential goods such as vaccines and medical equipment - have raised the concern that excessive international division of labor has overly heightened countries' reliance on foreign suppliers and GVCs, thus endangering governments' ability to deliver societal well-being (Dallas et al., 2021; Evenett, 2020). Assertions have been made that GVCs had become too complex and that they were not designed to operate in today's turbulent geopolitical landscape. Calls have therefore become increasingly loud for GVC policies that would make countries more resilient to global economic shocks.

A country's resilience is generally defined as its ability to rapidly return to delivering societal wellbeing in the wake of an economic disruption (Miroudot, 2020). In this respect, a country's participation in GVCs can influence resilience by affecting both the severity of a disruption's initial economic impact and the ability to rapidly bounce back post-disruption.

Current debates often equate resilience with selfsufficiency, but this can be misleading (OECD, 2020). It is of course true, that fully localized production reduces a country's exposure to shocks that disrupt foreign production or trade (e.g., the recent Suez Canal blockage). However, it also heightens a country's vulnerability to local disasters that curtail domestic production (e.g., hurricane Katrina). In other words, building resilience implies that countries should avoid putting all apples in the same basket, and GVCs can play an important role in ensuring this does not happen.

A more pertinent resilience-related concern for policymakers is thus how to ensure that a society's ability to deliver essential goods and services is sufficiently resistant to both local and foreign disruptions (Miroudot, 2020). First, is a country's supply base of essential goods sufficiently diversified so that they are not excessively dependent on GVC links with specific countries (including the home country) that are prone to production or trade disruptions? During the Covid-19 pandemic, for example, an often-heard concern was that several countries were excessively dependent on China for the supply of essential medical equipment (Evenett, 2020). During the 2021 Texas Power failure, then again, critics argued that the U.S. state was insufficiently connected to the country's electricity grid, making it overly vulnerable to local shocks. Second, does a country have ready-to-access substitutes in case a disruption to an existing GVC linkage occurs? This can be in the form of domestic or regional buffer stocks, or a country's ability to rapidly switch to domestic or foreign supply alternatives (even if they are not yet in use) to compensate for the disruption. During the Covid19 pandemic, for example, the US government was criticized for its poor stockpiling of medical masks pre-pandemic, but also praised for its ability to 
rapidly ramp up domestic production of masks (Gereffi, 2020).

Any policy response to these questions needs to acknowledge that companies generally grasp many of the risks related to international supply chain shocks and have already developed sophisticated risk management strategies to deal with them. Many firms have added agility to their supply chain by diversifying their supplier base, increasing manufacturing capacity and creating buffer stocks (Christopher \& Peck, 2004). Well before the start of the 2018 Sino-US trade war, for example, many companies have adopted a China Plus One strategy where they duplicated production in China and at least one other country to reduce their vulnerability to supply chain disruptions and currency fluctuations in any individual country.

The contribution of Gereffi et al. (2021) in this special collection offers new evidence about firms' resilience in mitigating supply chain disruptions through the reconfiguration of their GVCs. As the US-China trade war unfolded, they found that many affected firms in the apparel, automotive and electronics sectors were able to bypass newly imposed trade restrictions through two main strategies: (i) switching production locations, end markets and/or suppliers; and (ii) upgrading value chain activities. They thus suggest that the adoption of risk mitigation strategies in GVCs has undercut the effectiveness of traditional trade policies.

The ability of market forces to naturally push firms to develop their own risk mitigation strategies suggests that governments should resist the temptation to go too far in their efforts to enhance resilience. The key resilience-related policy question that governments face is thus to what extent there are market failures in a society's ability to deal with domestic or foreign disruptions in the delivery of essential goods and services, and how to address them.

Horner (2021)'s article in this special collection provides useful insights into how a government can address market failures in the development of resilience. In the article, the author focuses on countries that mostly have an import-oriented engagement with GVCs in essential goods - they act as an end market -and asks what governments can do to promote both their development and health policy interests. Using the example of South Africa's pharmaceutical industry, Horner demonstrates that the state's role as a facilitator in this context is limited, and that the government consequently turns to direct intervention such as state ownership and public procurement policies to attain their policy goals.

Indeed, there are several direct interventions that governments can conduct ex ante to enhance resilience. First, governments can develop buffering strategies such as stockpiling for essential products. Second, they can subsidize local production of essential goods or promote state ownership. Third, they can push for extra diversification of the supply base through their public procurement strategies.

Dialogue with the private sector and possibly even the organization of public-private platforms at the level of GVCs are needed to develop the appropriate government interventions (Hoekman, 2021). Simchi-Levi and Simchi-Levi (2020) have in this respect come up with an interesting proposal: similar to bank stress tests that were imposed after the Great Recession of 2008-2009, governments should work together with industries that provide essential goods to establish stress tests that capture a country's ability to deal with demand or supply disruptions. These stress tests should consider the government's own stockpiling strategy, the speed with which both local production and imports can be ramped up, the diversification of import sources, and the impact of potential export restrictions by other countries.

Finally, international cooperation should be an integral part of any resilience strategy. From the perspective of government authorities, agreements to share essential goods, to conduct joint procurements at a bilateral or regional level and to limit export restrictions can facilitate diversification and risk sharing.

\section{HOW ARE GVC-ORIENTED POLICIES DIFFERENT? THE TRIFECTA OF TASKS, LINKAGES, AND FIRMS}

Careful observers will notice that the distinction between GVC-oriented policies and traditional public policies does not lie in their social or economic objectives. Policymakers were using public policy tools to boost trade integration and to strengthen specialization in higher value-added industries well before they started paying attention to GVCs. Redistributive and resiliency concerns have also been on the agenda in traditional IB policy discussions.

The different weights that international organizations and government agencies put on GVC objectives nonetheless lead to systematic variations 
in GVC-oriented policies across policy agencies (Gereffi, 2019b; Mayer \& Gereffi, 2019). Depending on their ideological heritage and focus, policy agencies sponsor more minimalist or rather more interventionist GVC policies. For instance, the World Trade Organization's traditional focus is more on trade without discrimination, therefore primarily promoting relatively minimalist, facilitative, and horizontal GVC participation policies. By contrast, the International Labor Organization has developed the Decent Work Agenda and therefore the emphasis in GVC policies is on inclusive development promoting employment creation, social protection and MNEs' involvement in social upgrading. Similarly, as emphasized by De Marchi and Alford (2021) in this special collection, at national level different policy actors can have diverse interests and objectives across ministries (i.e., the Ministry of Agriculture or Industry vs. the Ministry of Equal Opportunities or Social Affairs) and across geographical jurisdictions (i.e., central, provincial or municipal authorities). Policy coordination is often a problem, and a value chainspecific approach has been proposed to formulate and implement GVC-oriented policies (Findlay \& Hoekman, 2021, in this special collection).

Taking this perspective, the novel policy descriptions come from the elevated role that is given to the trifecta of tasks, linkages, and firms, which has pushed local, regional and national governments to change the economic rationales for conducting policy interventions and which has altered the range of instruments they can use to attain policy goals.

GVC-oriented policies put the spotlight on the development of fine-grained GVC tasks instead of the traditional focus on entire industries. As we have seen, a central aim of participation policies is to boost functional specialization so that countries can concentrate on those tasks in which they have a comparative advantage. A key goal of value capture policies is to help countries create and appropriate more value by conducting the existing activities better or by functionally upgrading into higher value-added tasks. In both cases, policymakers are pushed to adopt a more granular view of the type of activities that they should target to promote economic development through structural transformation.

GVC-oriented policies also lay greater emphasis on the role of linkages than traditional development policies. A key insight from GVC studies is that a firm's economic performance and the social conditions that it offers to its workers are heavily influenced by its value chain connections. Interfirm linkages to foreign partners can act as a powerful conduit for accessing foreign knowledge and resources that can be leveraged to improve technological and operational capabilities. Decent work parameters imposed by foreign value chain partners can incentivize firms to improve their local work conditions. Economic shocks to foreign value chain partners can be transmitted to local firms through supply chains. A focal concern of policymakers is thus how to properly regulate, deepen, and strengthen GVC linkages so that they can promote both economic and social upgrading while at the same time guaranteeing a country's economic resilience.

GVC-oriented policies finally elevate the role of firms, both of lead firms and their suppliers, and a fine-grained microeconomic focus is called for. GVC scholarship recognizes the essential role that lead firms play in defining the terms and conditions of GVC membership and thus considers harnessing their behavior to be a potent approach to accomplish policy objectives. Some GVC-oriented policies in this respect may promote a partnership between public and private actors in which policymakers collaborate with GVC lead firms to upgrade local suppliers, ensure fair treatment of workers, adopt environmentally sustainable business practices, and build resiliency (Abdulsamad \& Manson, 2019; Gereffi, 2019b). Furthermore, GVC-oriented policies recognize the essential objective of supporting suppliers' efforts to enter - and nurture profitable relationships with lead firms, exploiting the potential offered by these relationships for their own learning and capability development. This further strengthens the argument that GVC-oriented policies elevate the role of linkages and firms.

The GVC literature's emphasis on the trifecta of tasks, linkages, and firms has exposed a new set of market failures that provide a potent narrative for new policy rationales (Pietrobelli \& Staritz, 2018). The non-rival and partially excludable nature of intangibles - which are at the heart of some of the highest value-added and therefore most desirable tasks in a GVC (e.g., R\&D and marketing) - create public good problems that need to be addressed through government intervention (Jaax \& Miroudot, 2021; Van Assche, 2020). Market externalities abound in lead firms' willingness to share knowledge through their GVC linkages and the development of suppliers' capabilities to absorb it (Guerrieri \& Pietrobelli, 2004; Pietrobelli \& Staritz, 2018). Market forces do little to engender social 
upgrading, environmental upgrading and economic resilience. For these reasons, there is a loudening call among GVC scholars for moving beyond the traditional development policies built around the so-called Washington Consensus, which focuses on minimalist state intervention, and to adopt more potent trade, industrial and innovation policies (Neilson, 2014; Werner et al., 2014).

Moreover, an increasingly prominent viewpoint is that the global scope of GVCs has hampered countries' capacity to address some key GVCrelated market failures (Kobrin, 2015). This produces two main consequences: on the one hand supra-national policies and institutions need to be reformed to address the GVC-related market and coordination failures that individual countries' governments cannot fix. The recent G7 proposal for a minimum global corporate tax rate to close cross-border tax loopholes is a good example of this. On the other hand, governments are also being forced to partner up with the private sector to address "governance gaps" (Scherer \& Palazzo, 2011; Eberlein, 2019; Goerzen et al., 2021). That is, there is a growing call for private actors such as lead firms and non-governmental organizations to play an active role in filling gaps in global regulation and in resolving global public good problems. To reconcile private sector interests, policy makers should take on a brokering role in 'value chain coalitions', facilitating dialogues between public and private stakeholders (Morris et al., 2012).

The trifecta of tasks, linkages, and firms at the heart of GVC-oriented policies also implies that governments need to rely on new instruments and actions to reach their policy goals. In some cases, it provides policymakers with new levers in their policy toolbox. Many state-led export credit agencies, for example, have expanded the type of firms to which they can provide trade financing in order to reflect the growing reality of GVCs (Van Assche $\&$ Gangnes, 2019). Whereas in the past they relied on push strategies that provided financing to support the export sales of domestic firms, they now increasingly adopt pull strategies where they give loans and export credits to large foreign companies, insofar this helps facilitate the integration of domestic firms into GVCs. In other cases, existing policy instruments are rendered less potent. For example, GVCs allow firms to more easily circumvent trade policy barriers (Ma \& Van Assche, 2014). To avoid a country-specific trade policy, a lead firm no longer has to relocate its entire value chain to another country, but only a single value chain stage, often final assembly. Gereffi et al. (2021) in this special collection indeed found that many firms in the apparel, automotive and electronics sectors were able to bypass trade restrictions related to the US-China trade war by switching production locations, end markets and suppliers.

Redesigning policy instruments for new GVC realities, however, is often easier said than done. Once the trifecta of tasks, linkages, and firms is considered, it becomes clear that policymakers need to take into consideration the complementarities between various at-the-border and beyondthe-border policies, e.g., the operation of a GVC makes it necessary to look at trade promotion, innovation and industrial policies to support local suppliers, at training policy to produce the required skills, at infrastructural policy to facilitate exports and imports, at the availability of advisory services in the areas of standards and certifications as well as at labor, social and environmental regulations. Each policy needs to be assessed in light of its systemic scope and influence, moving beyond the traditional "silos" approach where each Government Ministry and Agency pursues its own objectives independently. Moreover, the frontier has had to be moved beyond national borders to interact with global buyers, thus overcoming the traditional distinction between policies for the domestic and the foreign market. Therefore, even if many elements of policy were already present long time ago, the advent of GVCs has forced to rethink them in such a deep fashion, that the whole set of policies oriented to GVCs has now become a truly different concept.

\section{CONCLUSION}

GVC-oriented policies differ from traditional public policies since they account for the elevated role that the trifecta of tasks, linkages, and firms play in today's global economy and since they propose new policy instruments that can be used to target the promotion of diverse, and not always complementary, economic and societal goals. We have shown that these policies require a systemic approach that covers various domains including innovation, trade and industrial policy, infrastructure, education and training policies, and service provision. They also require assessing the heterogeneous impact of policies on firms, workers, and other stakeholders and considering both national 
and sub-national differences as well as supra-national concerns. These policies extend far beyond the market-enabling interventions of the Washington Consensus, and often entail a vertical and selective approach.

A major contribution of the special collection is the evidence on unintended consequences of various policies on GVCs, a theme on which there is still substantial room for theory building. In other words, the complex architecture and the deep interactions prevailing in GVCs may produce the result that a policy that was intended to have a specific effect (e.g., the imposing of trade restrictions) could for example have an unanticipated effect on industry behavior and technological change. Thus, Gereffi et al. (2021) find that firms during the US-China trade war attempted to mitigate the impact of trade restrictions by economically upgrading their GVC activities. In the case of reshoring policies in the UK West Midlands, Pegoraro et al. (2021) also discover that one of the unexpected effects was fostering technological upgrading. Both findings suggest that the relation between trade restrictions, GVC participation and GVC value capture is non-linear, something which needs to be further investigated. On a separate topic, Goerzen et al. (2021) find that institutions have a highly variegated influence on the effectiveness of private governance, suggesting that more theoretical research is needed on the links between institutions, private governance and public governance.

Another key contribution is showing the importance of developing new data and combining existing databases to study the effects of GVCoriented policies. Despite the availability of new aggregate databases (e.g., the OECD's Trade in Value Added -TiVA- and the UNCTAD-Eora GVC databases) that have opened the floodgates for quantitative research on GVCs (Antràs \& Chor, 2021; Sturgeon, 2019), more is needed to allow empirical research to catch up with GVC theory with a focus on the role of policies (Frederick, 2019). In this special collection, Jaax and Miroudot (2021) combine the TiVA dataset with information on factor income to study the determinants of income related to intangibles in GVCs. Furthermore, Bam et al. (2021) associate input-output statistics for South Africa with product space data to identify which tasks should be the target of industrial policies. These are promising developments that are necessary to empirically test the wealth of new policy proposals that has been coming out of the GVC literature.

Aside from advances in aggregate statistics, there is also a need for new micro data and empirical analysis on the strategies and decision-making processes that firms and other actors in GVCs take to deal with the repercussions of GVC-oriented policy (Sako \& Zylberberg, 2019; Sturgeon, 2019). International business scholars are particularly well positioned to take on this challenge. As pointed out by Gereffi et al. (2021), researchers should in this respect move beyond industry-specific analysis (e.g., footwear in Mexico) and more fully embrace both comparative and longitudinal studies. Comparative analysis across companies or industries allows researchers to assess the influence of firm and sector characteristics on the relation between public policy and GVCs. Longitudinal analysis is critical for evaluating dynamic trends which are at the heart of the interactions and possible trade-offs among economic, social and environmental upgrading.

Indeed, this is a theme that has only received limited uptake both in this special collection and in the wider literature: How do GVC-oriented policies differentially impact multiple policy goals? GVC studies have shown that there are trade-offs between economic, social and environmental upgrading (De Marchi \& Alford, 2021), but the connections to policy have been underexplored. Furthermore, there has been little work studying the cross-influence that the same policy interventions may have on several policy objectives (Álvarez, Crespi \& Volpe Martincus, 2012). This is an important lacuna in the literature since policyrelated trade-offs abound. Resiliency policies, for example, may increase a firm or region's ability to deal with external shocks at the cost of its GVC participation or value capture. Labor standards may promote social upgrading at the detriment of GVC participation or value capture. As we reflect on the role that GVCs can play on sustainable recovery (Zhan, 2021), it is clear that more theoretical and empirical research is needed on the trade-offs and inconsistencies that emerge when GVC-oriented policies are used to address multiple policy goals. Getting a better grasp on these will go a long way in developing a systemic and evidence-based vision of 
GVC-oriented policies that transcends a government's or international organization's ideological heritage.

\section{ACKNOWLEDGEMENTS}

We would like to thank Gary Gereffi, Sarianna Lundan and Sébastien Miroudot for their comments on an earlier version of this paper.

Author contributions All authors contributed equally to this study and are ranked alphabetically.

\section{NOTES}

${ }^{1}$ In the literature, "dynamic rents" are identified as: (i) resource rents, "gifts of nature", in which a producer has access to relatively better land or resource; (ii) innovation rents endogenously created by producers through the systematic application of knowledge to production (Freeman, 1974; Schumpeter 1934); (iii) exogenous rents where producers may benefit from access to better forms of infrastructure, lower costs and directed financial intermediation, better trained workforce, etc.; and (iv) market rents, which arise through exclusive or near-exclusive control over input and product markets (Davis et al., 2018).

\section{REFERENCES}

Abdulsamad, A., \& Manson, H. 2019. Public-private partnerships in global value chains. In Handbook on global value chains. Edward Elgar Publishing (pp. 537-554).

Alvarez, R., Crespi, G., \& Martincus, C. V. 2012. Impact evaluation in a multiple program world. Inter-American Development Bank.

Amendolagine, V., Presbitero, A. F., Rabellotti, R., \& Sanfilippo, M. 2019. Local sourcing in developing countries: The role of foreign direct investments and global value chains. World Development, 113: 73-88.

Ambos, B., Brandl, K., Perri, A., Scalera, V. G., \& Van Assche, A. 2021. The nature of innovation in global value chains. Journal of World Business, 56(4): 101221.

Antràs, P., \& Chor, D. (2021). Global Value Chains. WP 28149, NBER, Cambridge MA, https://www.nber.org/system/files/ working_papers/w28549/w28549.pdf

Anzolin, G., \& Pietrobelli, C. 2021. Local content policies: Why mining need consistent policy packages to support capabilities development. The Extractive Industries and Society. https://doi. org/10.1016/j.exis.2020.11.013.

Bair, J., Anner, M., \& Blasi, J. 2020. The political economy of private and public regulation in post-Rana Plaza Bangladesh. ILR Review, 73(4): 969-994.
${ }^{2}$ The firm level database is provided by the Business Social Compliance Initiative (BSCI), an initiative of the Foreign Trade Association which umbrellas more than 1,500 firms ranging from small and medium enterprises to MNCs. WGI (available at https://info.worldbank.org/ governance/wgi/, accessed on 16th April 2021) reports aggregate and individual governance indicators for over 200 countries and territories over the period 1996-2019, for six dimensions of governance.

${ }^{3}$ AGOA is the African Growth and Opportunity Act between the USA and the African countries. EBA is Everything but Arms, a trade preferential scheme between the EU and 49 least developed countries. SACU is Southern African Customs Union comprising South Africa and its border countries. SADC is the Southern African Development Community, a regional economic community among 16 African countries.

${ }^{4}$ Linkages have been on the policy agenda for a long time, but for different reasons. For example, UNCTAD (2001) focused on technology transfer and FDI, not on GVCs.

${ }^{5}$ On June 2021 G7 financial ministers have reached an historical agreement to reform the global tax system (https://www.reuters.com/ business/g7-nations-near-historic-deal-taxingmultinationals-2021-06-05/ accessed June 8th 2021)

Bam, W. G., De Bruyne, K., \& Laing, M. 2021. The IO-PS in the context of GVC-related policymaking: The case of the South African automotive industry. Journal of International Business Policy. https://doi.org/10.1057/s42214-020-00081-7.

Barrientos, S., Gereffi, G., \& Rossi, A. 2011. Economic and social upgrading in global production networks: A new paradigm for a changing world. International Labour Review, 150(3-4): 319340.

Bathelt, H., Malmberg, A., \& Maskell, P. 2004. Clusters and knowledge: Local buzz, global pipelines and the process of knowledge creation. Progress in Human Geography, 28(1): 3156.

Bems, R., Johnson, R. C., \& Yi, K. M. 2013. The great trade collapse. Annual Review of Economics, 5(1): 375-400.

Bird, Y., Short, J., \& Toffel, M. 2019. Coupling labor codes of conduct and supplier labor practices: The role of internal structural conditions. Organization Science, 30: 847-867.

Bird, R. C., \& Soundararajan, V. 2020. The role of precontractual signals in creating sustainable global supply chains. Journal of Business Ethics, 164(1): 81-94.

Blyde, J., Pietrobelli, C., \& Volpe, C. (2014). A World of Possibilities: Internationalization for Productive Development, Chapter 8. In G. Crespi, E. Fernandez-Arias, \& E. H. Stein (Eds.), Rethinking Productive Development: Sound Policies and 
Institutions for Economic Transformation (pp. 233-278). Palgrave.

Buckley, P. J. 2009. The impact of the global factory on economic development. Journal of World Business, 44(2): 131143.

Buckley, P. J., \& Strange, R. 2015. The governance of the global factory: Location and control of world economic activity. Academy of Management Perspectives, 29(2): 237-249.

Buckley, P. J., Strange, R., Timmer, M. P., \& de Vries, G. J. 2020. Catching-up in the global factory: Analysis and policy implications. Journal of International Business Policy, 3: 79-106.

Cano-Kollmann, M., Cantwell, J., Hannigan, T. J., Mudambi, R., \& Song, J. 2016. Knowledge connectivity: An agenda for innovation research in international business. Journal of International Business Studies, 47: 255-262.

Chen, W., Los, B., \& Timmer, M. (2018). Factor Incomes in Global Value Chains: The Role of Intangibles. NBER Working Paper, No. 25242, http://www.nber.org/papers/w25242.

Christopher, M., \& Peck, H. 2004. Building the resilient supply chain. The International Journal of Logistics Management, 15(2): $1-14$.

Constantinescu, C., Mattoo, A., \& Ruta, M. 2019. Does vertical specialisation increase productivity? The World Economy, 42(8): 2385-2402.

Contractor, F. .., \& Kundu, S. K. 1998. Modal choice in a world of alliances: Analyzing organizational forms in the international hotel sector. Journal of International Business Studies, 29(2): 325-356.

Crespi, G., Fernández-Arias, E., \& Stein, E. (2014). Investing in ideas: policies to foster innovation. In G. Crespi (Ed.), Rethinking productive development (pp. 61-106). New York: Palgrave Macmillan.

Dallas, M. P., Horner, R., \& Li, L. 2021. The mutual constraints of states and global value chains during COVID-19: The case of personal protective equipment. World Development, 139: 105324.

Davis, D., Kaplinsky, R., \& Morris, M. 2018. Rents, power and governance in global value chains. Journal of World-Systems Research, 24(1): 43-71.

De Marchi, V., \& Alford, M. 2021. State policies and upgrading in global value chains: A systematic literature review. Journal of International Business Policy. https://doi.org/10.1057/s42214021-00107-8.

De Marchi, V., Di Maria, E., Golini, R., \& Perri, A. 2020. Nurturing international business research through global value chains literature: A review and discussion of future research opportunities. International Business Review. https:// doi.org/10.1016/j.ibusrev.2020.101708.

De Marchi, V., Di Maria, E., Krishnan, A., \& Ponte, S. (2019). Environmental upgrading in global value chains. In G. Gereffi, S. Ponte, G. Raj-Rechert (Eds.), Handbook on global value chains (pp. 310-323). Edward Elgar:

Distelhorst, G., \& Locke, R. M. 2018. Does compliance pay? Social standards and firm-level trade. American Journal of Political Science, 62(3): 695-711.

Durand, C., \& Milberg, W. 2019. Intellectual monopoly in global value chains. Review of International Political Economy, 27(2): 404-429.

Eberlein, B. 2019. Who fills the global governance gap? Rethinking the roles of business and government in global governance. Organization Studies, 40(8): 1125-1145.

Escaith, H., Keck, A., Nee, C., \& Teh, R. (2011). Japan's earthquake and tsunami: International trade and global supply chain impacts. VOXEU, April, 28. https://voxeu.org/article/ japans-earthquake-and-tsunami-global-supply-chain-impacts

Evenett, S. J. 2020. Chinese whispers: COVID-19, global supply chains in essential goods, and public policy. Journal of International Business Policy, 3(4): 408-429.

Findlay, C., \& Hoekman, B. 2021. Value chain approaches to reducing policy spillovers on international business. Journal of
International Business Policy. https://doi.org/10.1057/s42214020-00083-5.

Foldy, B. (2020). Coronavirus pinching car industry supply chains. Market Watch. https://www.marketwatch.com/story/ coronavirus-pinching-car-industry-supply-chains-2020-0214 ? mod=mw_quote_news

Frederick, S. 2019. Global value chain mapping. In Handbook on global value chains. Edward Elgar Publishing (pp. 29-53).

Freeman, C. 1974. The economics of industrial innovation. Penguin Education.

Gammelgaard, J., Haakonsson, S., \& Just, S. N. 2021. Linking Malawi's agricultural sector to global value chains: The case for community governance. Journal of International Business Policy. https://doi.org/10.1057/s42214-021-00101-0.

Gereffi, G. (2019a). Economic upgrading in global value chains. In G. Gereffi, S. Ponte \& G. Raj-Reichert (Eds.), Handbook on Global Value Chains (pp. 240-254). Edward Elgar: Cheltenham, UK and Lyme, US.

Gereffi, G. 2019. Global value chains and international development policy: Bringing firms, networks and policy-engaged scholarship back in. Journal of International Business Policy, 2(3): 195-210.

Gereffi, G. 2020. What does the COVID-19 pandemic teach us about global value chains? The case of medical supplies. Journal of International Business Policy, 3(3): 287-301.

Gereffi, G., Lim, H. C., \& Lee, J. 2021. Trade policies, firm strategies, and adaptive reconfigurations of global value chains. Journal of International Business Policy. https://doi. org/10.1057/s42214-021-00102-z.

Gereffi, G., Humphrey, J., \& Sturgeon, T. 2005. The governance of global value chains. Review of International Political Economy, 12(1): 78-104.

Gereffi, G., \& Sturgeon, T. (2013). Global value chain-oriented industrial policy: The role of emerging economies. Chapter 14. In D. Elms \& P. Low (Eds.), Global value chains in a changing world (pp. 329-360). Geneva: WTO Publications.

Giuliani, E., Ciravegna, L., Vezzulli, A., \& Kilian, B. 2017. Decoupling standards from practice: The impact of in-house certifications on coffee farms' environmental and social conduct. World Development, 96: 294-314.

Giuliani, E., Pietrobelli, C., \& Rabellotti, R. 2005. Upgrading in global value chains: Lessons from Latin American clusters. World Development, 33(4): 549-573.

Goerzen, A., \& Van Assche, A. (2020). Global value chain governance: a MNC capabilities view. Chapter 21. In K. Mellahi, K. Meyer, R. Narula, I. Surdu \& A. Verbeke (Eds.) The Oxford Handbook of International Business Strategy (pp. 421434). Oxford: Oxford University Press.

Goerzen, A., Iskander, S. P., \& Hofstetter, J. 2021. The effect of institutional pressures on business-led interventions to improve social compliance among emerging market suppliers in global value chains. Journal of International Business Policy. https://doi.org/10.1057/s42214-020-00064-8.

Grossman, G. M., \& Rossi-Hansberg, E. 2008. Trading tasks: A simple theory of offshoring. American Economic Review, 98(5): 1978-1997.

Guerrieri, P., \& Pietrobelli, C. 2004. Industrial districts' evolution and technological regimes: Italy and Taiwan. Technovation, 24(11): 899-914.

Hansen, T., \& Hansen, U. E. 2020. How many firms benefit from a window of opportunity? Knowledge spillovers, industry characteristics, and catching up in the Chinese biomass power plant industry. Industrial and Corporate Change, 29(5): 12111232.

Horner, R. 2017. Beyond facilitator? State roles in global value chains and global production networks. Geography Compass, 11(2): e12307.

Horner, R. 2021. Global value chains, import orientation, and the state: South Africa's pharmaceutical industry. Journal of International Business Policy. https://doi.org/10.1057/s42214021-00103-y. 
Humphrey, J., \& Schmitz, H. 2002. How does insertion in global value chains affect upgrading in industrial clusters? Regional Studies, 36(9): 1017-1027.

Jaax, A., \& Miroudot, S. 2021. Capturing value in GVCs through intangible assets: The role of the trade-investment-intellectual property nexus. Journal of International Business Policy. https:// doi.org/10.1057/s42214-020-00086-2.

Kobrin, S. J. 2015. Is a global nonmarket strategy possible? Economic integration in a multipolar world order. Journal of World Business, 50(2): 262-272.

Krishnan, A., te Velde, D. W., \& Were, A. (2018). Kenya-UK trade and investment relations. Taking stock and promoting exports to the UK. Overseas Development Institute (ODI).

Lee, K. 2013. Capability failure and industrial policy to move beyond the middle- income trap: from trade- based to technology- based specialization. In J. E. Stiglitz, \& J. Y. Lin (Eds.), The industrial policy revolution I. The Role of Government Beyond Ideology. Basingstoke: Palgrave Macmillan: 244-272.

Lema, R., Pietrobelli, C., \& Rabellotti, R. (2019). Innovation in global value chains. In G. Gereffi, S. Ponte \& G. Raj-Reichert (Eds.), Handbook on global value chains (pp. 370-384). Edward Elgar: Cheltenham, UK and Lyme, US.

Lema, R., Fu, X., \& Rabellotti, R. 2020. Green windows of opportunity: Latecomer development in the age of transformation toward sustainability. Industrial and Corporate Change, 29(5): 1193-1209.

Locke, R. M. 2013. The promise and limits of private power: Promoting labor standards in a global economy. Cambridge: Cambridge University Press.

Locke, R., Amengual, M., \& Mangla, A. 2009. Virtue out of necessity? Compliance, commitment, and the improvement of labor conditions in global supply chains. Politics \& Society, 37(3): 319-351.

Lund-Thomsen, P. 2020. Corporate social responsibility: A supplier-centered perspective. Environment and Planning a: Economy and Space, 52(8): 1700-1709.

Lund-Thomsen, P., \& Lindgreen, A. 2014. Corporate social responsibility in global value chains: Where are we now and where are we going? Journal of Business Ethics, 123(1): 11-22.

Ma, A. \& Van Assche, A. (2014). Vertical specialization, tariff shirking and trade. Chapter 5. In B. Ferrarini \& D. Hummels (réd.), Asia and Global Production Networks: Implications for Trade, Incomes and Economic Vulnerability (pp. 148-178). London: Asian Development Bank and Edward Elgar Publishing.

Martinez-Covarrubias, J. L., Lenihan, H., \& Hart, M. 2017. Public support for business innovation in Mexico: a cross-sectional analysis. Regional Studies, 51(12): 1786-1800.

Mayer, F., \& Gereffi, G. 2010. Regulation and economic globalization: Prospects and limits of private governance. Business and Politics, 12(3): 1-25.

Mayer, F., \& Gereffi, G. 2019. International development organizations and global value chains. Handbook on global value chains. Edward Elgar: 570-584.

Mayer, F. W., \& Phillips, N. 2017. Outsourcing governance: states and the politics of a 'global value chain world.' New Political Economy, 22(2): 134-152.

Milberg, W., liang, X., \& Gereffi, G. (2014). Industrial policy in the era of vertically specialized industrialization. Transforming economies: Making industrial policy work for growth, jobs and development, pp. 151-178.

Miroudot, S. 2020. Reshaping the policy debate on the implications of COVID-19 for global supply chains. Journal of International Business Policy, 3(4): 430-442.

Montalbano, P., Nenci, S., \& Pietrobelli, C. 2018. Opening and linking up: Firms, global value chains and productivity in Latin America. Small Business Economics, 50(4): 917-935. https:// doi.org/10.1007/s11187-017-9902-6.

Morris, M., Kaplinsky, R., \& Kaplan, D. 2012. "One thing leads to another"-Commodities, linkages and industrial development. Resources Policy, 37(4): 408-416.
Morris, M., \& Staritz, C. 2019. Industrialization paths and industrial policy for developing countries in global value chains. Edward Elgar Publishing.

Morrison, A., Pietrobelli, C., \& Rabellotti, R. 2008. Global value chains and technological capabilities: A framework to study learning and innovation in developing countries. Oxford Development Studies, 36(1): 39-58.

Nachum, L. 2021. Value distribution and markets for social justice in global value chains: Interdependence relationships and government policy. Journal of International Business Policy. https://doi.org/10.1057/s42214-021-00105-w.

Narula, R. 2019. Enforcing higher labor standards within developing country value chains: Consequences for MNEs and informal actors in a dual economy. Journal of International Business Studies, 50(9): 1622-1635.

Navas-Alemán, L. 2011. The impact of operating in multiple value chains for upgrading: The case of the Brazilian furniture and footwear industries. World Development, 39(8): 13861397.

Neilson, J. 2014. Value chains, neoliberalism and development practice: The Indonesian experience. Review of International Political Economy, 21(1): 38-69.

OECD. (2020). Shocks, risks and global value chains : insights from the OECD METRO model. http://www.oecd.org/trade/ documents/shocks-risks-gvc-insights-oecd-metro-model.pdf

Pahl, S., \& Timmer, M. P. 2020. Do global value chains enhance economic upgrading? A long view. The Journal of Development Studies, 56(9): 1683-1705

Pasquali, G., Godfrey, S., \& Nadvi, K. 2021. Understanding regional value chains through the interaction of public and private governance: Insights from Southern Africa's apparel sector. Journal of International Business Policy. https://doi.org/ 10.1057/s42214-020-00071-9.

Pegoraro, D., De Propris, L., \& Chidlow, A. 2021. Regional factors enabling manufacturing reshoring strategies: A case study perspective. Journal of International Business Policy. https://doi.org/10.1057/s42214-021-00112-x.

Pietrobelli, C. (2021a) Cross-border innovation and global value chains. The role of public policies. In D. Castellani, A. Perri, V. Scalera \& A. Zanfei (Eds.), Cross-border innovation in a changing world. Players, places and policies. Oxford: Oxford University Press, forthcoming.

Pietrobelli, C. 2021b. New industrial innovation policies in a world of global value chains. In K. Lee, J. D. Lee, S. Radosevic, D. Meissner, \& N. Vonortas (Eds.), The challenges of technology and economic catch-up in emerging economies. Oxford: Oxford University Press.

Pietrobelli, C., \& Rabellotti, R. 2011. Global value chains meet innovation systems: Are there learning opportunities for developing countries? World Development, 39(7): 1261-1269.

Pietrobelli, C., \& Staritz, C. 2018. Upgrading, interactive learning, and innovation systems in value chain interventions. The European Journal of Development Research, 30(3): 557574.

Ponte, S. 2020. The hidden costs of environmental upgrading in global value chains. Review of International Political Economy. https://doi.org/10.1080/09692290.2020.1816199.

Ponte, S., \& Ewert, J. 2009. Which way is "up" in upgrading? Trajectories of change in the value chain for South African wine. World Development, 37(10): 1637-1650.

Posthuma, A., \& Nathan, D. 2010. Labour in global production networks. Oxford University Press.

Rossi, A. 2019. Applying the GVC framework to policy: The ILO experience. Journal of International Business Policy, 2(3): 211216.

Sachs, J. D., \& Sachs, L. E. 2021. Business alignment for the "Decade of Action." Journal of International Business Policy, 4(1): 22-27.

Sako, M., \& Zylberberg, E. 2019. Supplier strategy in global value chains: Shaping governance and profiting from upgrading. Socio-Economic Review, 17(3): 687-707. 
Scherer, A. G., \& Palazzo, G. 2011. The new political role of business in a globalized world: A review of a new perspective on CSR and its implications for the firm, governance, and democracy. Journal of Management Studies, 48(4): 899-931.

Schmitz, H., \& Knorringa, P. 2000. Learning from global buyers. Journal of Development Studies, 37(2): 177-205.

Schumpeter, J. A. 1934. The theory of economic development. Harvard University Press.

Seidman, G. W. 2009. Beyond the Boycott: Labor rights, human rights and transnational activism. Russell Sage Foundation.

Simchi-Levi, D., \& Simchi-Levi, E. 2020. We need a stress test for critical supply chains. Brighton: Harvard Business Review.

Stolzenburg, V., Taglioni, D., \& Winkler, D. 2019. Economic upgrading through global value chain participation: which policies increase the value-added gains? Edward Elgar Publishing.

Sturgeon, T. J. 2019. Measuring global value chains. In Handbook on global value chains. Edward Elgar Publishing (pp. 7790).

Taglioni, D., \& Winkler, D. 2016. Making global value chains work for development. The World Bank.

Timmer, M. P., Miroudot, S., \& de Vries, G. J. 2019. Functional specialisation in trade. Journal of Economic Geography, 19(1): $1-30$.

Tokatli, N. 2012. Toward a better understanding of the apparel industry: A critique of the upgrading literature. Journal of Economic Geography, 13(6): 993-1011.

Trindade, V. 2005. The big push, industrialization and international trade: The role of exports. Journal of Development Economics, 78(1): 22-48.

Turkina, E., \& Van Assche, A. 2018. Global connectedness and local innovation in industrial clusters. Journal of International Business Studies, 49(6): 706-728.

UNCTAD. 2001. World investment report promoting linkages. Geneva: UNCTAD.

Van Assche, A. (2017). Global value chains and the rise of a global supply chain mindset. Chapter 13 . In S. Tapp, A. Van Assche, \& R. Wolfe (Eds.), Redesigning Canadian Trade Policies for New Global Realities (pp 183-208). Montréal: McGillQueen's University Press.

Van Assche, A. (2020). Trade, investment and intangibles: The $A B C s$ of global value chain-oriented policies. OECD Trade Policy Papers, No. 242, OECD Publishing, Paris.

Van Assche, A., \& Gangnes, B. 2019. Global value chains and the fragmentation of trade policy coalitions. Transnational Corporations Journal, 26(1): 31-60.

Van Assche, A., \& Van Biesebroeck, J. 2018. Functional upgrading in China's export processing sector. China Economic Review, 47: 245-262.

Werner, M., Bair, J., \& Fernández, V. R. 2014. Linking up to development? Global value chains and the making of a post-
Washington Consensus. Development and Change, 45(6): 1219-1247.

Whitfield, L., Staritz, C., \& Morris, M. 2020. Global value chains, industrial policy and economic upgrading in Ethiopia's apparel sector. Development and Change, 51(4): 1018-1043.

World Bank. (2019). World development report 2020: Trading for development in the age of global value chains. The World Bank.

Zhan, J. X. 2021. GVC transformation and a new investment landscape in the 2020s: Driving forces, directions, and a forward-looking research and policy agenda. Journal of International Business Policy, 4(2): 206-220.

\section{ABOUT THE AUTHORS}

Carlo Pietrobelli is a professor and policy advisor on innovation and industrial development and policy. He is currently Professor and Dean of the Department of Economics at University Roma Tre, Italy, and Professorial Fellow at UNU-MERIT, Maastricht. During 2009-2016 was a Lead Economist at the Inter- American Development Bank. His research interests range from development economics to innovation, trade, industry and natural resources in developing countries. He has published widely in international journals and his books were published by Harvard University Press, Edward Elgar, Palgrave and Routledge.

Roberta Rabellotti is Professor of Economics at the University of Pavia. Her research focuses on global value chains, industrial clusters and innovation in emerging countries.

Ari Van Assche is Professor of International Business at HEC Montréal and deputy editor of the Journal of International Business Policy. His research focuses on the organization of global value chains and their implications for international trade, industrial clusters and public policy.

Publisher's Note Springer Nature remains neutral with regard to jurisdictional claims in published maps and institutional affiliations.

Accepted by Sarianna Lundan, editor-in-chief, 28 May 2021. This article has been with the authors for two revisions. 